\title{
Cross-linking of Atrial Natriuretic Peptide to Binding Sites in Rat Olfactory Bulb Membranes
}

\author{
Gary M. Wildey ${ }^{1}$ and Christopher C. Glembotski \\ Department of Pharmacology, School of Medicine, University of Pennsylvania, Philadelphia, Pennsylvania 19104
}

\begin{abstract}
Binding sites for ${ }^{125}$ I-atrial natriuretic peptide (ANP) ${ }^{2}$ in rat olfactory bulb membranes have been studied using pharmacological and biochemical methods. Various unlabeled ANP-related peptides were tested for the ability to inhibit the binding of the radioligand in membrane binding assays. ANP(92-126) and ANP(99-126) were the most potent inhibitors tested, both exhibiting an $\mathrm{IC}_{50}$ value of 0.40 nM. ANP(103-126) and ANP(103-123) were 3 and 70 times less potent, respectively. ANP(111-126) was unable to inhibit the binding of the radioligand at a concentration of $1 \mu \mathrm{M}$. Several peptides unrelated to ANP were unable to inhibit the binding of the radioligand to rat olfactory bulb membranes. Membranes labeled with ${ }^{125} \mathrm{I}-$ ANP were incubated with cross-linking agents and subjected to SDS-PAGE followed by autoradiography. A band possessing an apparent molecular mass of $116 \mathrm{kDa}$ was identified. The labeling of this band was progressively decreased by increasing concentrations of unlabeled ANP(99-126) $\left(\mathrm{IC}_{50}=0.6 \mathrm{nM}\right)$ and by several other ANP-related peptides at nanomolar concentrations. For comparison purposes, ANP binding sites in rat aorta membranes were labeled with ${ }^{125}$ I-ANP and cross-linked using identical techniques. Three bands possessing molecular masses of 120,72 , and $62 \mathrm{kDa}$ were identified. These results indicate that the ANP binding site in rat olfactory bulb membranes displays pharmacological and biochemical properties similar to peripheral ANP receptors.
\end{abstract}

Atrial natriuretic peptide (ANP) is a general term used to describe a family of bioactive peptides recently identified in mammalian cardiac atria. It is now clear from amino acid sequencing and subsequent cDNA analyses that all of the ANP peptides isolated from the heart are derived from the COOH-terminal region of a single, large precursor (see Cantin and Genest, 1985; De Bold, 1985: Needleman et al., 1985, for reviews). While this family of atrial peptides was originally discovered based upon diuretic and natriuretic activities (De Bold et al., 1981), these peptides were subsequently shown to produce vasorelaxation (Winquist, 1985) and inhibition of adrenal aldosterone secretion

\footnotetext{
Received Apr. 10, 1986; revised June 18, 1986; accepted June 19, 1986.

This work was supported by American Heart Association Grant-in-Aid 84653 , with funds contributed in part by the Philadelphia Chapter of the American Heart Association, and Biomedical Research Support Grant SO7-RR-05415-24 awarded by the Division of Research Resources, NIH. C.C.G. is an Established Investigator of the American Heart Association. We would like to thank Cheryl Fisher and Marion Oronzi for help with the autoradiography. In addition, we thank Tom Gibson, Paul Shields, Peter Vos, and Barry Wolfe for their interest and suggestions during the course of this work.

Correspondence should be addressed to Christopher C. Glembotski, Molecular Biology Institute and the Department of Biology, San Diego State University, San Diego, CA 92182

'Present address: Cellular and Molecular Research Laboratory, Cardiac Unit, Massachusetts General Hospital, Boston, MA 02114.

${ }^{2}$ Terminology: The nomenclature used to describe the ANP peptides is based upon the precursor of ANP, rat ANP $(1-128)$, which does not contain the signal sequence. Using this nomenclature, the radioligand used in this study corresponds to iodinated ANP(99-126).
}

Copyright (C) 1986 Society for Neuroscience $0270-6474 / 86 / 123767-10 \$ 02.00 / 0$
(Campbell et al., 1985; Chartier et al., 1984; Goodfriend et al., 1984; Matsuoka et al., 1985). The molecular form of ANP that is believed to interact with peripheral organs is ANP(99-126). This 28 amino acid peptide has been isolated and sequenced from rat plasma and is assumed to be derived from the $\mathrm{COOH}$ terminal region of atrial ANP (Manning et al., 1985; Schwartz et al., 1985). This hypothesis is supported by recent studies indicating that cardiac atrial cells secrete a $15 \mathrm{kDa}$ form of ANP, likely ANP(1-126), which is cleaved by a plasma component to form ANP(99-126) (Bloch et al., 1985; Glembotski and Gibson, 1985). The physiological importance of the COOH-terminal region of ANP was suggested by the demonstration that conversion of the large, atrial form of ANP to smaller forms by enzymatic treatment results in increased bioactivity in isolated smooth muscle preparations (Currie et al., 1984).

A new direction for ANP research was opened by the recent immunohistochemical localization of atrial peptides in rat brain (Jacobowitz et al., 1985; Kawata et al., 1986; Saper et al., 1985; Skofitsch et al., 1986). ANP immunoreactive neurons were distributed in several regions of the brain but were most prominent in the anteroventral region of the third ventricle (AV3V). The distribution of ANP immunoreactive material in the rat brain has also been quantitated by radioimmunoassay (Kawata et al., 1986; Zamir et al., 1986). ANP immunoreactive material in the hypothalamus has been characterized using biochemical techniques coupled with radioimmunoassay (Glembotski et al., 1985; Tanaka et al., 1984; Zamir et al., 1986). The physiological significance of the ANP immunoreactive material found in the brain remains to be elucidated; however, the distribution of ANP immunoreactive neurons is consistent with their potential involvement in the regulation of fluid balance. In support of this idea, 2 studies investigating the effects of ANP in the CNS have demonstrated that (1) ANP injected into the AV3V is capable of raising blood pressure and heart rate (Sills et al., 1986), and (2) ANP injected into the third ventricle is able to antagonize the dipsogenic effects of angiotensin II (Nakamura et al., 1985).

As with other peptide hormones and neurotransmitters, ANP is thought to produce its physiological effects by interacting with specific cell surface receptors on appropriate target tissues. Using radioligand binding techniques, high-affinity membrane binding sites specific for ANP have been identified and characterized in renal (Carrier et al., 1985; Napier et al., 1984), vascular (Hirata et al., 1984; Napier et al., 1984; Schenk et al., 1985; Schiffrin et al., 1985), and adrenal tissues (De Lean et al., 1984; Misono et al., 1985; Schiffrin et al., 1985). ANP binding sites have also been identified in these tissues by autoradiography (Lynch et al., 1986; Von Schroeder et al., 1985). Evidence that these peripheral binding sites may, in fact, represent physiological receptors for ANP is derived from the close correlation between the bioactive and pharmacological potencies of various ANPrelated peptides (Napier et al., 1984; Schiffrin et al., 1985). Recently, biochemical studies using either photoactive derivatives of ANP or chemical cross-linking agents have identified a 

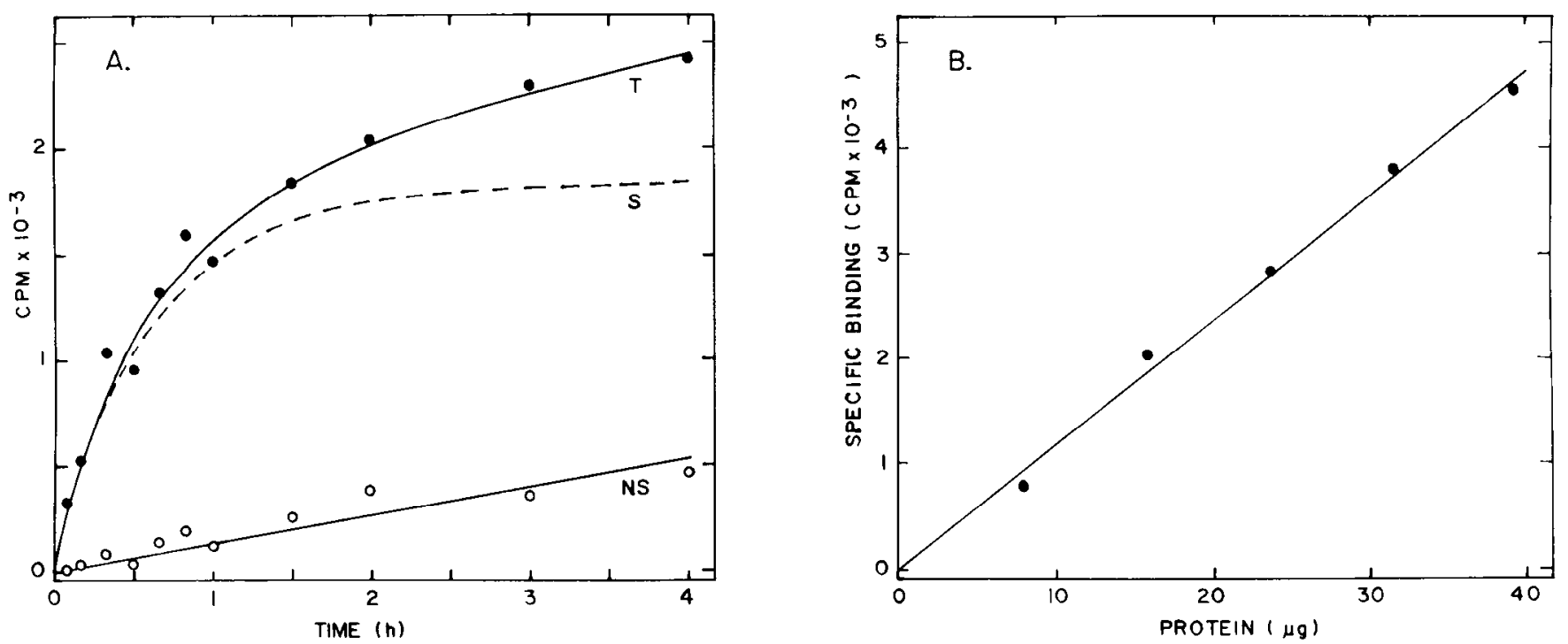

Figure 1. Characterization of the binding of ${ }^{125} \mathrm{I}$-ANP to rat olfactory bulb membranes. $A$, Time course: Membranes (15 $\mu \mathrm{g}$ protein) were incubated with 100 pM ${ }^{125} \mathrm{I}-\mathrm{ANP}$ for varying lengths of time at $4^{\circ} \mathrm{C}$ in the absence $(T)$ or presence $(N S)$ of $1 \mu \mathrm{M}$ unlabeled ANP(99-126). The amount of radioactivity bound was determined by vacuum filtration as described in Materials and Methods. The amount of specifically bound radioactivity $(S)$ was determined by subtracting the nonspecific from the corresponding total radioactivity bound. $B$, Tissue concentration dependence: Increasing amounts of membrane protein were incubated with $100 \mathrm{pM}^{125}$ I-ANP in a constant volume of assay buffer $(100 \mu \mathrm{l})$ in the presence and absence of $1 \mu \mathrm{M}$ unlabeled $\Lambda \mathrm{NP}(99-126)$ for $2 \mathrm{hr}$ at $4^{\circ} \mathrm{C}$. The amount of specifically bound radioactivity was determined as described above.

protein band displaying an apparent molecular mass of 120 $140 \mathrm{kDa}$ as the putative ANP binding site in bovine and rat adrenal cortical membranes (Hirose et al., 1985; Misono et al., 1985 ) and in rat kidney cortical membranes (Yip et al., 1985). However, in rabbit aorta (Vandlen et al., 1985) and bovine adrenal cortical (Meloche et al., 1986) membranes, and in cultured bovine endothelial and smooth muscle cells (Schenk et al., 1985), a protein band with an approximate molecular mass of 60-70 kDa was prominently labeled using both photoaffinity ligands and chemical cross-linking agents.

In the CNS, specific binding sites for ANP have been demonstrated in discrete regions of the rat, guinea pig, and monkey brain using autoradiography (Gibson et al., 1986; Quirion et al., 1984,1986 ). The highest levels of these binding sites were found to be distributed in brain regions thought to be involved in cardiovascular regulation (subfornical organ, area postrema), as well as in the olfactory bulb. Further characterization of ANP binding sites in the CNS is necessary to help determine whether these binding sites represent ANP receptors. In this paper we report the pharmacological and structural characterization of ANP binding sites in the CNS using rat olfactory bulb membrane preparations. Established homobifunctional cross-linking agents were used in this study to identify the putative ANP binding site.

\section{Materials and Methods}

\section{Materials}

Synthetic peptides were obtained from Penninsula Labs [ANP analogs, thyrotropin-releasing hormone (TRH)], Bachem [ $\beta$-endorphin, D-alanine-D-leucine enkephalin (DADLE), $\alpha$-melanocyte stimulating hormone $(\alpha-\mathrm{MSH})$ ], or Sigma Chemical Co. (insulin, vasopressin, angiotensin II). (3-125I-iodotyrosyl ${ }^{28}$ ) rat ANP (125I-ANP) (1960-2090 Ci/mmol) was purchased from Amersham. Cross-linking agents and 2-mercaptoethanol were obtained from Pierce Chemical Co. Electrophoresis chemicals were obtained from BDH Chemical, Ltd. Aprotinin, 1,10-o-phenanthroline, and all other biochemicals were purchased from Sigma Chemical Co.

\section{Membrane preparation}

Olfactory bulbs were dissected from male Sprague-Dawley rats (100$200 \mathrm{gm})$ and chilled in ice-cold wash buffer (150 mM NaCl, $5 \mathrm{~mm}$ Tris-
$\mathrm{HCl}$, pH 7.4). Tissue was then minced with a razor blade and homog-

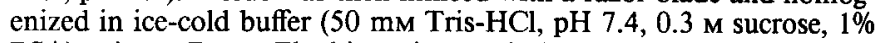
BSA) using a Potter-Elvehjem tissue grinder ( $1 \mathrm{ml}$ extraction buffer/ pair olfactory bulbs). The homogenate was centrifuged at $1000 \times g$ for $10 \mathrm{~min}$, and the resulting supernatant fluid was collected and centrifuged at $30,000 \times g$ for $30 \mathrm{~min}$ to obtain crude membrane pellets. Membrane pellets were resuspended in ice-cold binding buffer $(50 \mathrm{mM}$ Tris- $\mathrm{HCl}$, pH 7.4, $150 \mathrm{~mm} \mathrm{NaCl}, 5 \mathrm{~mm} \mathrm{MgCl}_{2}, 1 \% \mathrm{BSA}$ ) at 2-3 $\mathrm{mg}$ protein/ml, frozen in liquid nitrogen, and stored at $-20^{\circ} \mathrm{C}$.

Rat aortas were dissected free of accompanying fat and homogenized in ice-cold buffer using a mortar and pestle with sand added as an abrasive ( $1 \mathrm{rat}$ aorta/ $\mathrm{ml}$ of extraction buffer). Membranes were obtained as described above and stored at a concentration of $0.2 \mathrm{mg}$ protein $/ \mathrm{ml}$.

\section{Binding assay}

Stock membranes were quickly thawed, diluted with ice-cold binding buffer to which aprotinin and 1,10-o-phenanthroline were added [final concentration, 0.3 trypsin inhibitory units $(T I U) / m l$ and $100 \mu \mathrm{g} / \mathrm{ml}$, respectively] and rehomogenized. Routinely, $50 \mu \mathrm{l}$ of this diluted membrane preparation (approximately $20 \mu \mathrm{g}$ rat olfactory bulb or $10 \mu \mathrm{g}$ rat aorta membrane protein) was added to $50 \mu \mathrm{l}$ of binding buffer containing ${ }^{125}$ I-ANP and various concentrations of unlabeled peptides, as needed. The assay was terminated by diluting the reaction mixture with $4 \mathrm{ml}$ of ice-cold wash buffer followed by immediate filtration through glass fiber filter disks (Schleicher and Schuell \#30) under vacuum. Presoaking the filter disks in $0.1 \%$ polyethyleneimine (PEI) and having isotonic saline in the wash buffer were found to be important in obtaining low filter blanks (Misono et al., 1985; Napier et al., 1984; Schiffrin et al., 1985). Filters were placed in test tubes and counted for $2 \mathrm{~min}$ in an LKB Minigamma counter at $70 \%$ efficiency.

The concentration of ${ }^{125}$ I-ANP used in competition experiments was approximately $100 \mathrm{pm}(25,000-30,000 \mathrm{cpm} /$ assay tube). For these analyses, 10 concentrations of unlabeled ANP-related peptides were included, spanning 5 orders of magnitude. Other compounds unrelated to ANP were included at concentrations indicated in the text. Unlabeled peptides were added as 100 -fold concentrates to assay tubes after being freshly diluted in binding buffer from stock solutions. Nonspecific binding was defined in the presence of $1 \mu \mathrm{M}$ ANP(99-126) and represented less than $25 \%$ of total binding using rat olfactory bulb and aorta membranes.

\section{Peptide stability studies}

Experiments were carried out to determine the stability of the peptide ligand under the assay conditions employed in this study. Binding assays 

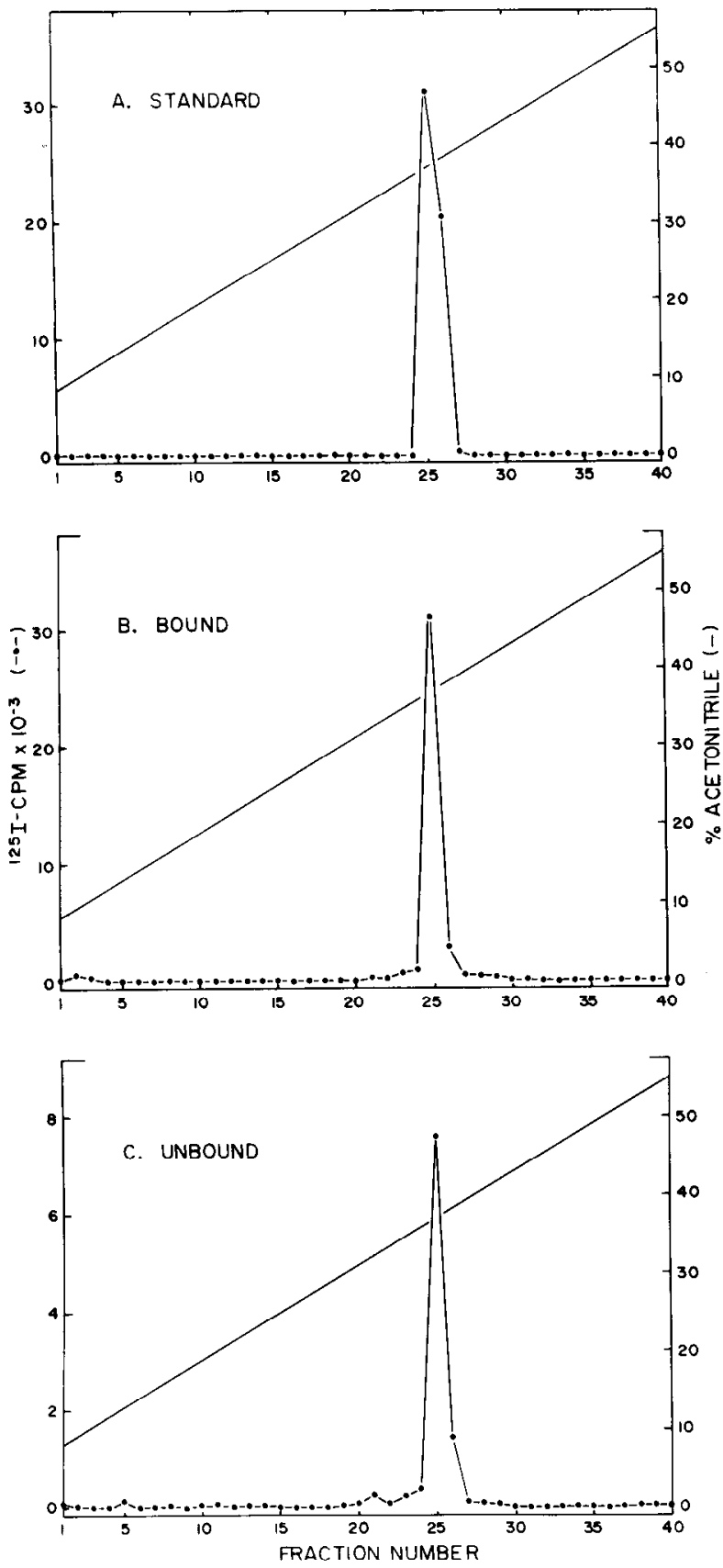

Figure 2. Chromatographic analysis of ${ }^{125}$ I-ANP after incubation with olfactory bulb membranes. $A$, Chromatograph of standard ${ }^{125}$ I-ANP: Stock ${ }^{125}$ I-ANP was analyzed by RP-HPLC using a $\mathrm{C}_{18}$ column equilibrated with $0.1 \%$ TFA. A gradient of acetonitrile from 4 to $76 \%$ was developed over $60 \mathrm{~min}$ at a constant flow rate of $1 \mathrm{ml} / \mathrm{min}$. Fractions were collected at $1 \mathrm{~min}$ intervals and analyzed for radioactivity. $B$, Chromatograph of ${ }^{125}$ I-ANP bound to pellet: Membranes (185 $\mu \mathrm{g}$ protein) were incubated with $100 \mathrm{pm}^{125} \mathrm{I}-\mathrm{ANP}$ for $2 \mathrm{hr}$ at $4^{\circ} \mathrm{C}$ and collected by centrifugation at $30,000 \times g$ for $30 \mathrm{~min}$. Radioligand was dissociated from the membranes by suspending the pellet in extraction buffer $(1 \%$ TFA, 5\% formic acid, $1 \mathrm{M} \mathrm{HCl}, 1 \mathrm{M} \mathrm{NaCl}$ ). The sample was prepared for RP-HPLC using a Sep-Pak $\mathrm{C}_{18}$ cartridge, as described in Materials and Methods and analyzed as described above. $C$, Representative chromatograph of unbound ${ }^{125}$ I-ANP present in the assay medium: A routine binding assay was terminated by centrifugation, and the resulting supernatant fluid was collected and analyzed by RP-HPLC, as described in $B$. The recovery of radioactivity averaged $90 \%$ for these analyses. This experiment was performed 3 additional times, yielding results similar to those shown. were performed under the standard conditions described above except that the assay was terminated by adding $400 \mu \mathrm{l}$ of ice-cold wash buffer to the test tubes, followed by centrifugation at $30,000 \times \mathrm{g}$ for $30 \mathrm{~min}$ to separate bound from free ligand. The resulting supernatant fluid was added to 4 vol of ice-cold extraction buffer [ $1 \%$ trifluoroacetic acid (TFA), $5 \%$ formic acid, $1 \mathrm{~m} \mathrm{HCl}, 1 \% \mathrm{NaCl}$ (Bennet et al., 1981), frozen and thawed, then applied to Sep-Pak $\mathrm{C}_{18}$ cartridges (Watcrs). Radiolabeled ANP was eluted from the cartridges with $3 \mathrm{ml}$ of $0.1 \%$ TFA containing $80 \%$ acetonitrile, evaporated under reduced pressure, reconstituted in $0.1 \%$ TFA, and analyzed by reversed-phase high-pressure liquid chromatography (RP-HPLC). RP-HPLC was performed using a Beckman model 334 gradient HPLC system and a $4 \times 250 \mathrm{~mm} \mathrm{C}{ }_{18}$ $\mu$ Bondapak column (Waters) with the trifluoroacetic TFA/acetonitrile buffer system described previously (Bennet et al., 1981). Fractions of HPLC eluate were collected at 1 min intervals and counted in an LKB Minigamma counter. Greater than $90 \%$ of the radioactivity collected from the supernatant fluid of the centrifuged binding assay mixtures was routinely recovered in the RP-HPLC fractions.

The stability of the bound ligand was examined in one experiment. This was performed essentially as described above except that (1) the binding assay was scaled up 10 -fold $(1 \mathrm{ml}$ of total assay mixture) to obtain enough bound ${ }^{125}$ I-ANP for study, and (2) the binding assay was diluted with $9 \mathrm{ml}$ of ice-cold wash buffer prior to centrifugation, with the resulting pellet being resuspended in $2.0 \mathrm{ml}$ of ice-cold extraction buffer.

\section{Chemical cross-linking studies}

The volume of the binding assay described above was scaled up to 1 $\mathrm{ml}$ for cross-linking studies. After $2 \mathrm{hr}$ of incubation, a $100 \mu \mathrm{l}$ sample of the $1 \mathrm{ml}$ mixture was removed and the extent of binding was determined by vacuum filtration, as described above. The remainder of the mixture was diluted with $9 \mathrm{ml}$ of ice-cold wash buffer and centrifuged at $30,000 \times g$ for $30 \mathrm{~min}$ at $4^{\circ} \mathrm{C}$ to terminate the assay. The resulting membrane pellets were washed by resuspension in $10 \mathrm{ml}$ of ice-cold cross-linking buffer ( $50 \mathrm{~mm}$ sodium phosphate, $\mathrm{pH} 7.4,150 \mathrm{~mm} \mathrm{NaCl}$ ) and collected again by centrifugation. The resulting membrane pellets were resuspended in $1 \mathrm{ml}$ of ice-cold cross-linking buffer. Cross-linking agents were freshly prepared in dimethyl sulfoxide and routinely added in a volume not exceeding $5 \mu$ l. The final concentrations of cross-linking agents were $0.5 \mathrm{~mm}$ for disuccinimidyl suberate (DSS) and ethylene glycolyl bis(succinimidyl suberate) (EGS), and $1 \mathrm{~mm}$ for 1,5-difluoro2,4-dinitrobenzene (DFDNB), unless indicated otherwise. Cross-linking was allowed to proceed for $15 \mathrm{~min}$ at $4^{\circ} \mathrm{C}$. The cross-linking reaction was quenched by adding $100 \mu \mathrm{l}$ of $1.0 \mathrm{M}$ Tris- $\mathrm{HCl}, \mathrm{pH} 7.4$, followed by immediate centrifugation for $30 \mathrm{~min}$ at $30,000 \times \mathrm{g}$. The resulting membranc pellets were dissolved in $100 \mu \mathrm{l}$ of SDS-PAGE sample buffer $(1 \%$ SDS, $10 \%$ glycerol, $1 \% 2$-mercaptoethanol, $50 \mathrm{~mm}$ Tris-HCl, pH 6.8 ), boiled for $5 \mathrm{~min}$, and stored at $4^{\circ} \mathrm{C}$ until analyzed. Essentially all of the radioactivity expected from the filtration analysis of the $100 \mu \mathrm{l}$ sample was recovered in the gel sample.

\section{Electrophoresis}

Samples were centrifuged in a Beckman microfuge for $1 \mathrm{~min}$ to remove unsolubilized material and then analyzed by SDS-PAGE according to the dicontinuous method of Laemmli (Laemmli, 1970) using a $4.5 \%$ stacking gel and an $8.5 \%$ resolving gel. The ratio of acrylamide/bis was $38 / 1$. The thickness of the gel was $1.4 \mathrm{~mm}$. Equal amounts of rat olfactory bulb membrane protein were always applied to each lane of a gel, and ranged from 115 to $175 \mu \mathrm{g}$. After electrophoresis the resolving gels were stained with Coomassie Brilliant blue $(500 \mathrm{mg} / \mathrm{dl}$ dissolved in 25\% 2-propanol, 7\% glacial acetic acid), destained (5\% 2-propanol, $7 \%$ glacial acetic acid) and dried onto Whatman filter paper. Less than $5 \%$ of the applied radioactivity remained in the stacking gel after analysis. Autoradiograms were generated by apposing dried resolving gels against Kodak XAR-5 film for $2-3$ weeks at $-70^{\circ} \mathrm{C}$ and enhanced using Cronex intensifying screens. The molecular mass of labeled proteins was determined from a graph of the mobility of protein standards as a function of their molecular mass. The protein standards used to determine molecular mass were egg albumin ( $45 \mathrm{kDa})$, bovine albumin $(66$ $\mathrm{kDa}$ ), phosphorylase $\mathrm{b}(97.4 \mathrm{kDa}), \beta$-galactosidase $(116 \mathrm{kDa})$, and myo$\sin (205 \mathrm{kDa})$.

\section{Densitometric analysis of autoradiograms}

Densitometric analyses of autoradiograms were performed by a method similar to that previously described (Gibson et al., 1986). Autoradio- 


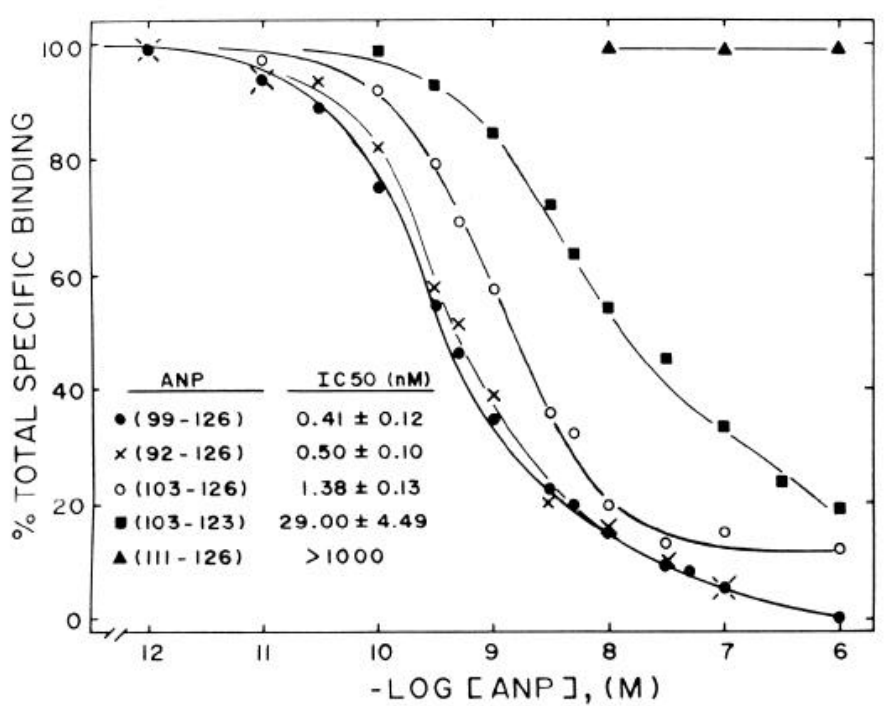

Figure 3. Effect of various ANP-related peptides on the binding of ${ }^{125}$ I-ANP to rat olfactory bulb membranes. Membranes (approximately $20 \mu \mathrm{g}$ protein) were incubated with $100 \mathrm{pm}^{125} \mathrm{I}-\mathrm{ANP}$ and varying concentrations of unlabeled ANP-related peptides for $2 \mathrm{hr}$ at $4^{\circ} \mathrm{C}$. The amount of specifically bound radioligand was determined in duplicate as described in Materials and Methods for each concentration of unlabeled peptide tested, and expressed as a percentage of the amount of ligand bound in the absence of unlabeled peptide. Competition curves generated by individual experiments were subjected to logit-log analysis to obtain $\mathrm{IC}_{50}$ values. The results shown (inset table) represent the average \pm SEM of 3-4 individual experiments for each of the peptides tested. Each point on the composite graph represents the average inhibition of ${ }^{125} \mathrm{I}$-ANP binding at the indicated concentration of peptide determined from 2-4 individual experiments, except for the points for ANP(111-126), which are taken from 2 experiments. In 3 typical experiments, the mean $( \pm$ SEM) total binding was $2321 \pm 56 \mathrm{cpm}$; and in the presence of $1 \mu \mathrm{M}$ unlabeled ANP(99-126), $769 \pm 38 \mathrm{cpm}$. Filter blanks averaged $275 \pm 12 \mathrm{cpm}$.

grams were placed over a photocell that recorded the transmittance of light from an overhead source, from which the optical density (O.D.) was calculated. For each lane on the autoradiogram, 6-8 readings were taken of each specifically labeled band, from which the surrounding background intensity of the given lane was subtracted.

\section{Protein determination}

Protein was determined by the method of Lowry (Lowry et al., 1951) using BSA as a standard. Aliquots of membrane preparations were centrifuged at $30,000 \times g$ for $30 \mathrm{~min}$ to obtain membrane pellets, which were dissolved in $1 \mathrm{~N} \mathrm{NaOH}$ prior to the assay.

\section{Results}

\section{Binding of ${ }^{125} I-A N P$ to rat olfactory bulb membranes}

Initial experiments demonstrated that ${ }^{125}$ I-ANP bound to olfactory bulb membranes such that equilibrium was attained after $2 \mathrm{hr}$ at $4^{\circ} \mathrm{C}$ (Fig. $1 \mathrm{~A}$ ). Under these conditions the amount of specifically bound ${ }^{125} \mathrm{I}$-ANP was linear with respect to tissue content (Fig. 1B).

Even though the binding assay was performed at $4^{\circ} \mathrm{C}$ in the presence of protease inhibitors, studies were performed to determine whether there was degradation of either the bound or free ${ }^{125} \mathrm{I}-\mathrm{ANP}$ during the $2 \mathrm{hr}$ incubation. RP-HPLC elution profiles of standard ${ }^{125}$ I-ANP were compared with those of ligand that had been exposed to tissue. One experiment examining the stability of ${ }^{125} \mathrm{I}$-ANP bound to rat olfactory bulb membranes demonstrated that essentially all of the radioactivity recovered from the membrane pellet (Fig. $2 B$ ) coeluted with standard ${ }^{125} \mathrm{I}-$ ANP (Fig. $2 A$ ). When the stability of the unbound ligand was examined, it was observed that $95 \%$ of the radioactivity present

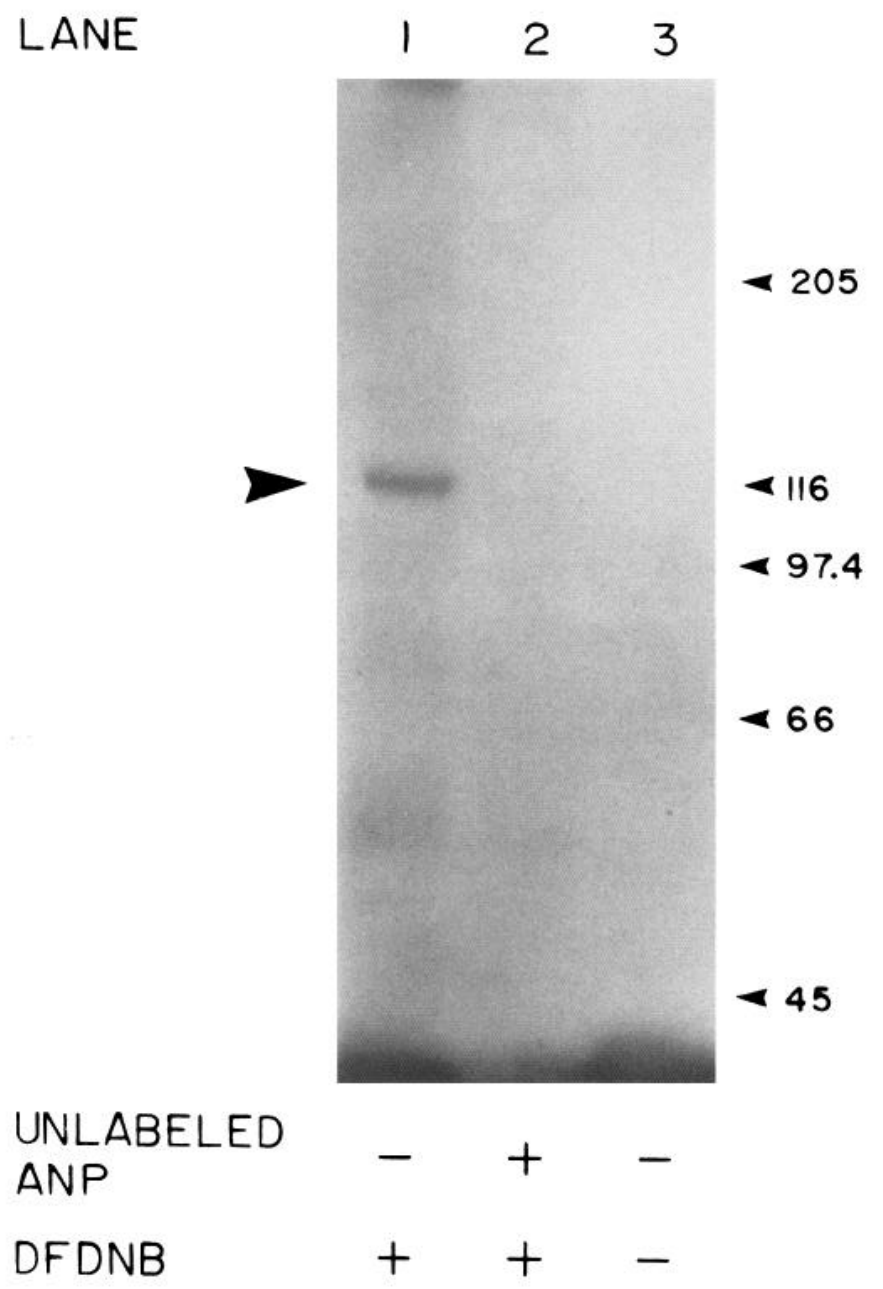

Figure 4. Autoradiogram of ${ }^{125}$ I-ANP crosslinked to binding sites in rat olfactory bulb membranes. Membranes (170 $\mu \mathrm{g}$ protein) were incubated with $100 \mathrm{pm}^{125} \mathrm{I}-\mathrm{ANP}$ for $2 \mathrm{hr}$ at $4^{\circ} \mathrm{C}$ in the presence (+) or absence $(-)$ of $1 \mu \mathrm{M}$ unlabeled ANP(99-126). The membranes were collected by centrifugation at $30,000 \times g$ for $30 \mathrm{~min}$ and resuspended in PBS in the absence $(-)$ or presence $(+)$ of $1 \mathrm{~mm}$ DFDNB. Dimethyl sulfoxide was added to the sample receiving no cross-linking agent. Membranes were subjected to SDS-PAGE and autoradiography as described in Materials and Methods. The migration of proteins of known molecular mass (in $\mathrm{kDa}$ ) is shown at right. The specifically labeled band is indicated by the arrow on the left.

in the binding assay medium after incubation with olfactory bulb membranes coeluted with standard ${ }^{125}$ I-ANP (Fig. 2C). Since the RP-HPLC properties of the labeled ligand were unchanged after incubation with rat olfactory bulb membranes, it was concluded that there was no significant proteolysis of ANP during the binding incubations.

Several ANP-related peptides were tested for the ability to compete with ${ }^{125} \mathrm{I}$-ANP for binding sites in olfactory bulb membranes. A composite graph of the inhibition curves generated by these experiments is shown in Figure 3. ANP(99-126) was equipotent with ANP(92-126) in the ability to inhibit the binding of radiolabeled ANP. ANP(103-126) was approximately one-third as potent as ANP(99-126), while ANP(103-123) was 70 times less potent. All of the inhibition curves appeared monophasic except for that of ANP(103-123), which was rather shallow. This could indicate that ANP(103-123) is interacting with a lower-affinity binding component, which has been reported previously (De Lean et al., 1984; Gibson et al., 1986; Napier et al., 1984). ANP(111-126) was unable to inhibit ${ }^{125}$ I-ANP bind- 
A.

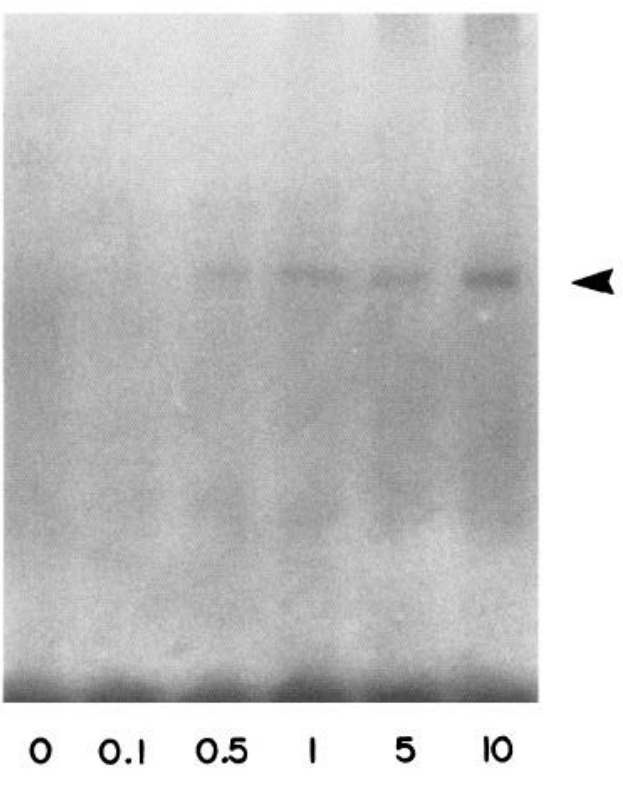

B.

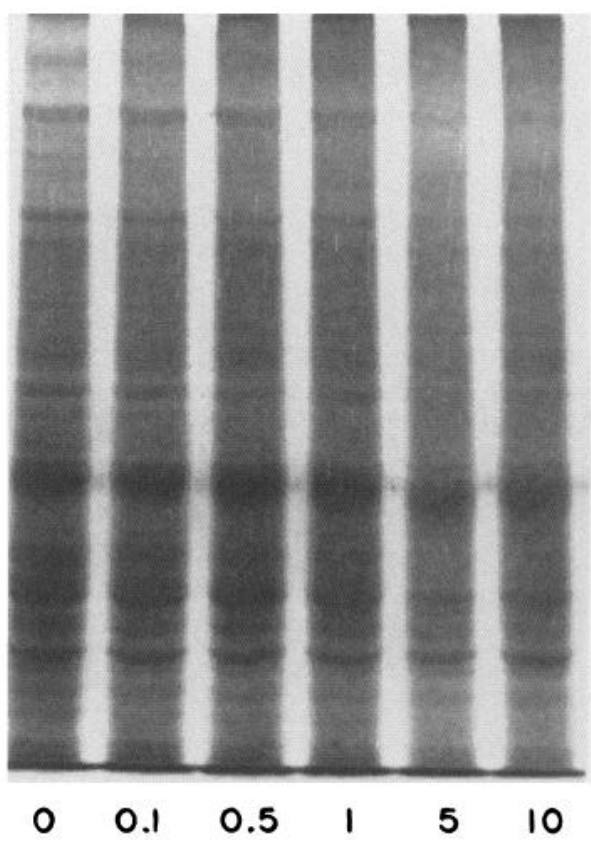

Figure 5. Effects of various concentrations of cross-linking agent. A, Autoradiogram of ${ }^{125}$ I-ANP binding sites in rat olfactory bulb membranes cross-linked with various concentrations of DFDNB: Membranes were incubated with $100 \mathrm{pm}^{125}$ I-ANP and cross-linked with the indicated concentrations of DFDNB. Dimethyl sulfoxide was added to the sample receiving no crcss-linking agent. Equal amounts of protein (115 $\mu \mathrm{g})$ were subjected to SDS-PAGE and autoradiography. The $116 \mathrm{kDa}$ band is indicated by the arrow on the right. $B$, Coomassie blue staining pattern of gel used to generate the autoradiogram shown in $A$.

ing to olfactory bulb membranes at concentrations up to $1 \mu \mathrm{M}$. These studies suggested that the binding site for ${ }^{125}$ I-ANP on rat olfactory bulb membranes exhibits specificity in its interaction with COOH-terminal fragments of rat ANP(1-128).

The specificity of these binding sites was further emphasized by the inability of various peptides unrelated to ANP to inhibit the binding of ${ }^{125}$ I-ANP to olfactory bulb membranes. In this regard, TRH, DADLE, ACTH(1-39), $\alpha$-MSH, insulin, glucagon, $\beta_{\mathrm{c}}$-endorphin(1-31), angiotensin II, and vasopressin were all ineffective at a concentration of $1 \mu \mathrm{M}$. Isoproterenol, phentolamine, atropine, $(+)$ butaclamol (all at $1 \mu \mathrm{M}$ ), and carbachol (1 $\mathrm{mm})$ were also without effect.

\section{Cross-linking studies of ${ }^{125} I-A N P$ to rat olfactory bulb membranes}

Established chemical cross-linking methods were used to identify the binding sites in rat olfactory bulb membranes which were labeled by ${ }^{125}$ I-ANP. The specificity of the membrane binding reaction was maintained in these experiments by scaling up the pharmacological assay 10 -fold. The homobifunctional crosslinking agent DFDNB was chosen for these studies because it had been used previously to label ANP receptors on rabbit aorta membranes and was also found to be the most efficient chemical cross-linking agent of several tested (Vandlen et al., 1985). Initial cross-linking studies using rat olfactory bulb membranes demonstrated that radioactivity was covalently incorporated into a single band displaying a molecular mass of about $116 \mathrm{kDa}$ when analyzed by SDS-PAGE (Fig. 4, lane 1). This band was not present when $1 \mu \mathrm{M}$ unlabeled ANP(99-126) was included in the binding mixture (Fig. 4, lane 2) and was not seen in the absence of cross-linking agent (Fig. 4, lane 3). Although bands of apparently lower molecular mass are often visible, they are more diffuse and less consistent in their intensity than the $116 \mathrm{kDa}$ band.
When the concentration of DFDNB was varied up to $10 \mathrm{~mm}$, a general increase in labeling of the $116 \mathrm{kDa}$ band was observed (Fig. 5A). Concentrations of DFDNB from 0.1 to $1.0 \mathrm{~mm}$ produced no alteration in the Coomassie blue staining pattern of the protein bands as compared to controls receiving no crosslinking agent, indicating that excessive cross-linking of membrane proteins was not occurring under these conditions (Fig. $5 B)$. At concentrations of DFDNB higher than $1 \mathrm{~mm}$, however, the protein band pattern became more diffuse. Therefore, all further experiments using this cross-linking agent were done at a concentration of $1 \mathrm{~mm}$.

Two other homobifunctional cross-linking agents, DSS and EGS, were also used to label the ${ }^{125} \mathrm{I}-\mathrm{ANP}$ binding site of rat olfactory bulb membranes. A protein band displaying an apparent molecular mass of $116 \mathrm{kDa}$ was again observed employing either cross-linking agent (Fig. 6). The concentration of DSS and EGS used in this experiment, $0.5 \mathrm{~mm}$, also produced no alteration in the Coomassie blue staining pattern of the protein bands (not shown).

The specificity of labeling of the $116 \mathrm{kDa}$ band by ${ }^{125} \mathrm{I}-\mathrm{ANP}$ was tested by scaling up the pharmacological competition binding assays previously described. The presence of increasing concentrations of unlabeled ANP(99-126) in the binding assay prior to cross-linking resulted in a progressive decrease in the labeling of the $116 \mathrm{kDa}$ band (Fig. $7 \mathrm{~A}$ ). The concentration of unlabeled ANP(99-126) that decreased the intensity of labeling of the 116 $\mathrm{kDa}$ band by $50 \%$ was estimated to be $0.6 \mathrm{~nm}$ by densitometric analysis (Fig. $7 B$ ). This value was similar to the $\mathrm{IC}_{5_{0}}$ value obtained previously in competition binding assays.

When various ANP-related peptides were all used at a constant concentration (1 nM), clear differences were observed in the abilities of the atrial peptides to inhibit the labeling of the $116 \mathrm{kDa}$ band (Fig. 8A). Upon densitometric analysis, it was apparent that the inhibitory abilities of the ANP-related pep- 
tides paralleled their rank order of potency in competition binding assays [i.e., ANP(99-126) > ANP(103-126) > ANP(103123) > ANP(111-126)] (Fig. 8B).

\section{Cross-linking of ${ }^{125} I-A N P$ to rat aorta membranes}

For comparison purposes the cross-linking of ${ }^{125} \mathrm{I}-\mathrm{ANP}$ to rat aorta membranes was performed. As expected, a $116 \mathrm{kDa}$ band was labeled when rat olfactory bulb membranes were used (Fig. 9, lane 1). Three bands were evident, however, when rat aorta membranes were used (Fig. 9, lane 3). The most intensely labeled band migrated with an apparent molecular mass of about 120 $\mathrm{kDa}$, while 2 minor bands displaying molecular masses of about 72 and $62 \mathrm{kDa}$ were also observed.

\section{Discussion}

In the present study, we have cross-linked ${ }^{125}$ I-ANP to an olfactory bulb membrane protein displaying a molecular mass of 116 kDa upon SDS-PAGE. The specificity of labeling of this band was insured by scaling up the pharmacological binding assay that had been rigorously tested for its specificity using several ANP-related peptides, as well as many peptides unrelated to ANP. Furthermore, the intensity of labeling of this band could be reduced in a dose-dependent manner using increasing concentrations of unlabeled ANP(99-126), and in a potency-dependent manner using various peptides related to ANP. Collectively, these results strongly suggest that the ANP binding sites in rat olfactory bulb membranes measured in pharmacological binding assays are visualized as the $116 \mathrm{kDa}$ band. This is the first identification of a specific ANP binding protein in the central nervous system.

\section{Molecular mass of ANP binding sites}

The concentrations of cross-linking agents used in this study were carefully determined such that there was no observable change in the Coomassie blue staining patterns of the membrane proteins compared to controls subjected to no cross-linking agents (Fig. 5). This indicated that neighboring membrane proteins were not covalently coupled to the binding protein. Therefore, the band visualized on autoradiographs represents a close approximation of the actual molecular mass of the ANP binding site in the rat olfactory bulb. Since the ANP bound to membranes was shown by HPLC studies to be structurally intact, an estimated molecular mass for the ANP binding site of $113 \mathrm{kDa}$ can be calculated by subtraction of the molecular mass of the crosslinked ANP (about $3 \mathrm{kDa}$ ) from $116 \mathrm{kDa}$. Since rat olfactory bulb membranes were reduced with 2-mercaptoethanol prior to SDS-PAGE, this $116-\mathrm{kDa}$ band is likely a monomer. However, the possibility that other minor bands are present but not apparent due to the experimental conditions employed in this study cannot be excluded.

Previous studies have identified the putative ANP receptor in several peripheral tissues. Using either photoactive derivatives of ANP or chemical cross-linking agents, only a single band was labeled in bovine and rat adrenal cortical membranes (Hirose et al., 1985; Misono et al., 1985) and in rat kidney cortical membranes (Yip et al., 1985). There is disagreement in these studies, however, over the effect of reducing agents on the apparent size of peripheral ANP receptors. In rat kidney cortex, the molecular mass of the ANP receptor was $140 \mathrm{kDa}$ in the absence or presence of dithiothreitol (DTT) (Yip et al., 1985). In bovine adrenal cortex, however, the apparent molecular mass of the ANP receptor was decreased from 130 to $70 \mathrm{kDa}$ under reducing conditions (Hirose et al., 1985). Another study identified 2 bands in bovine adrenal cortex, displaying molecular masses of 68 and $114 \mathrm{kDa}$, which were labeled by ${ }^{125} \mathrm{I}-\mathrm{ANP}$ in the absence or presence of 2-mercaptoethanol (Meloche et al., 1986). In rabbit aorta membranes both photoactive derivatives of ANP and chemical cross-linking agents labeled 3 bands dis-

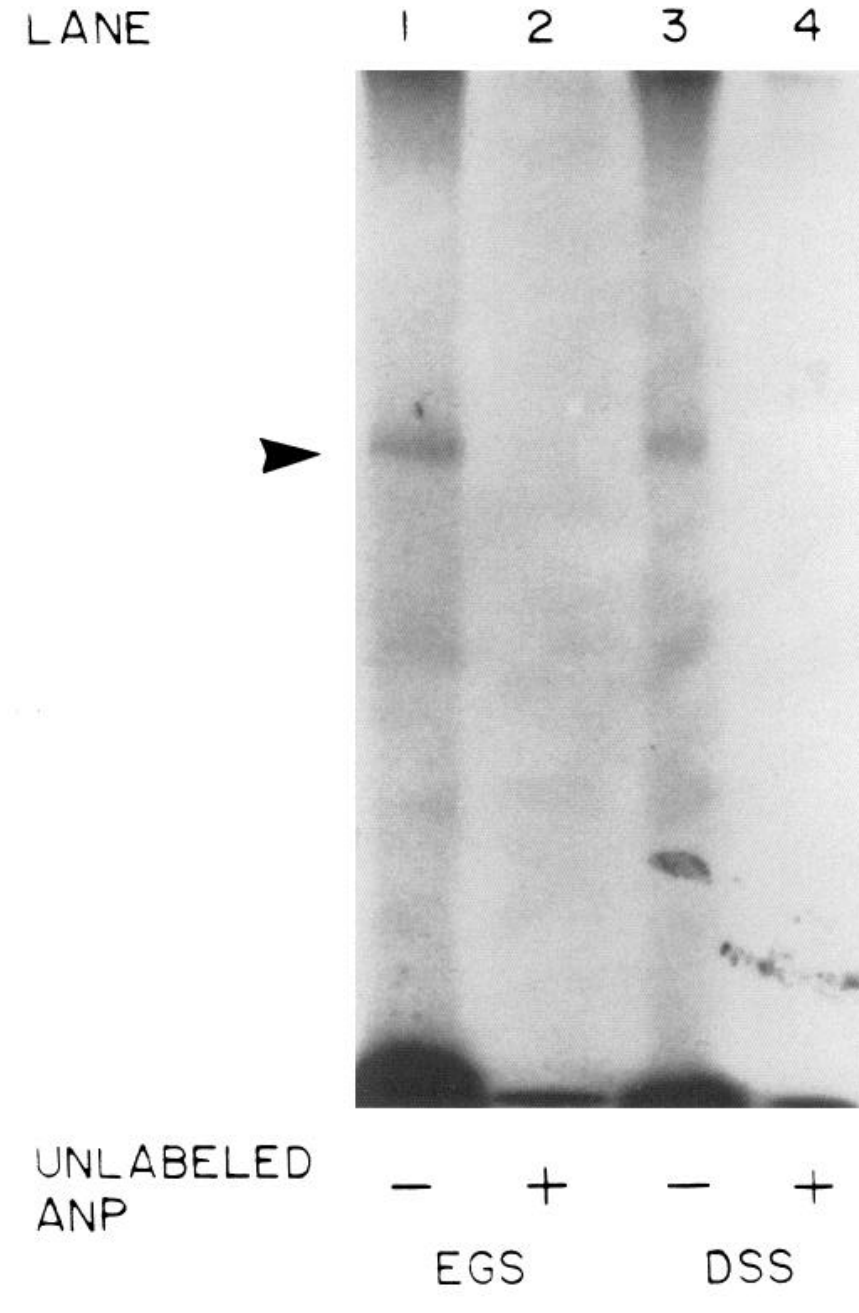

Figure 6. Autoradiogram of ${ }^{125} \mathrm{I}$-ANP binding sites cross-linked with EGS and DSS. Rat olfactory bulb membranes were incubated with 100 pM ${ }^{125} \mathrm{I}-\mathrm{ANP}$ in the absence $(-)$ or presence $(+)$ of $1 \mu \mathrm{M}$ ANP(99-126). Membranes were cross-linked with either 0.5 mM EGS (lanes 1 and 2 ) or $0.5 \mathrm{~mm}$ DSS (lanes 3 and 4 ) and equal amounts of protein were subjected to SDS-PAGE. The $116 \mathrm{kDa}$ band is indicated by the arrow on the left.

playing molecular masses of 120,70 , and $60 \mathrm{kDa}$ (Vandlen et al., 1985). This is similar to results obtained in the present study using rat aorta membranes (Fig. 9). The reason for the multiple labeled bands in aortic tissue is puzzling since another study demonstrated that when ${ }^{125} \mathrm{I}$-ANP was chemically cross-linked to cultured bovine aortic endothelial and smooth muscle cells, a protein band displaying a molecular mass of $66 \mathrm{kDa}$ was predominantly labeled in both cell types, with a minor band of approximately $180 \mathrm{kDa}$ (Schenk et al., 1985). Membranes were reduced with 2-mercaptoethanol prior to SDS-PAGE in each of the 2 studies utilizing vascular tissue.

\section{Pharmacology and physiology of ANP binding sites}

The ANP binding sites identified in the present report demonstrate pharmacological properties similar to ANP receptors located in peripheral organs. Several ANP-related peptides demonstrated high (nanomolar) affinities for the olfactory bulb ${ }^{125} \mathrm{I}-$ ANP binding sites in competition binding assays. The rank order of potency of ANP-related peptides [ANP(99-126) = ANP(92126) $>\mathrm{ANP}(103-126) \gg \mathrm{ANP}(103-123)]$ (see Fig. 3) indicated that alterations in the COOH-terminal region of ANP(99-126) affect binding potency to a greater extent than alterations in the 
A.

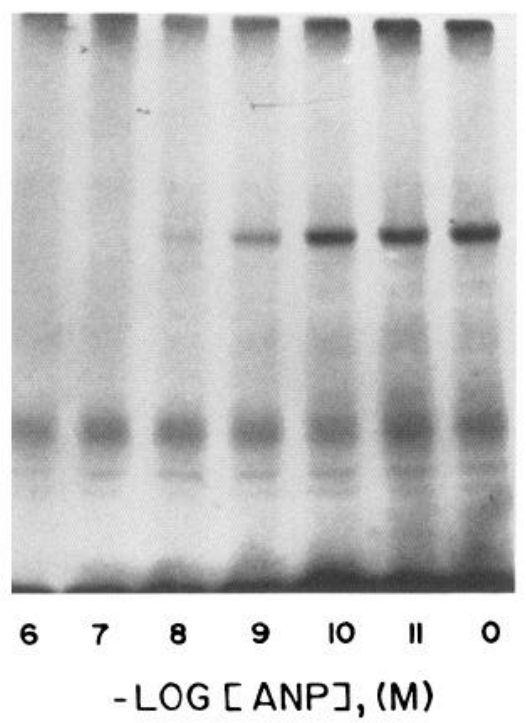

B.

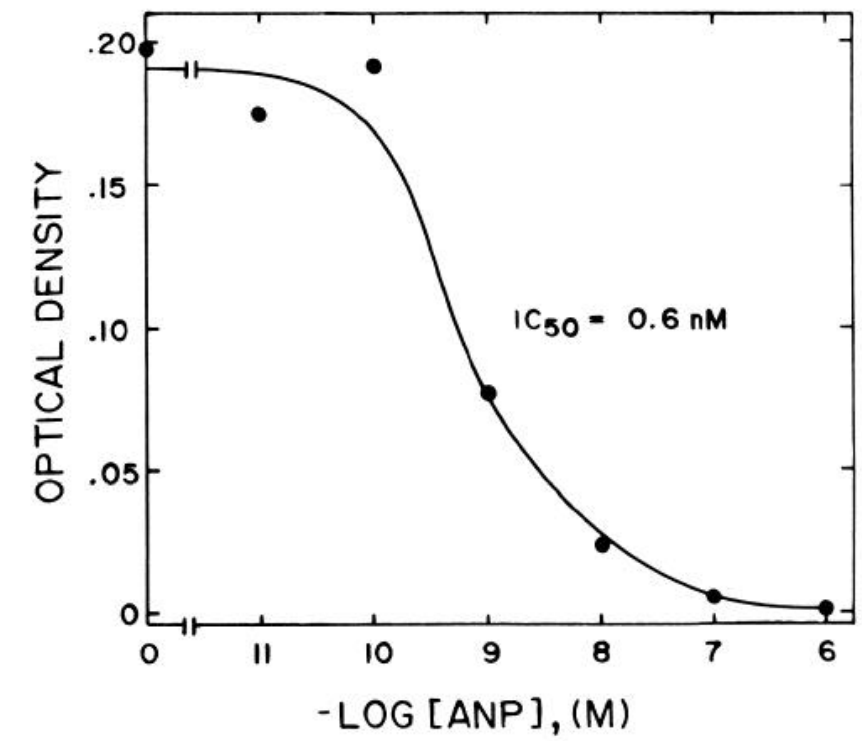

Figure 7. Inhibition of labeling of the $116 \mathrm{kDa}$ band by increasing concentrations of unlabeled ANP. A, Autoradiogram of rat olfactory bulb membranes: Membranes were incubated with 100 pM ${ }^{125}$ I-ANP in the presence of the indicated concentrations of unlabeled ANP(99-126). Membranes were cross-linked with $1 \mathrm{~mm}$ DFDNB, and equal amounts of protein were subjected to SDS-PAGE. The $116 \mathrm{kDa}$ band is indicated by the arrow on the right. $B$, Inhibition curve: An inhibition curve was generated by densitometric analysis of the intensity of the labeling of the 116 kDa band in $A$.
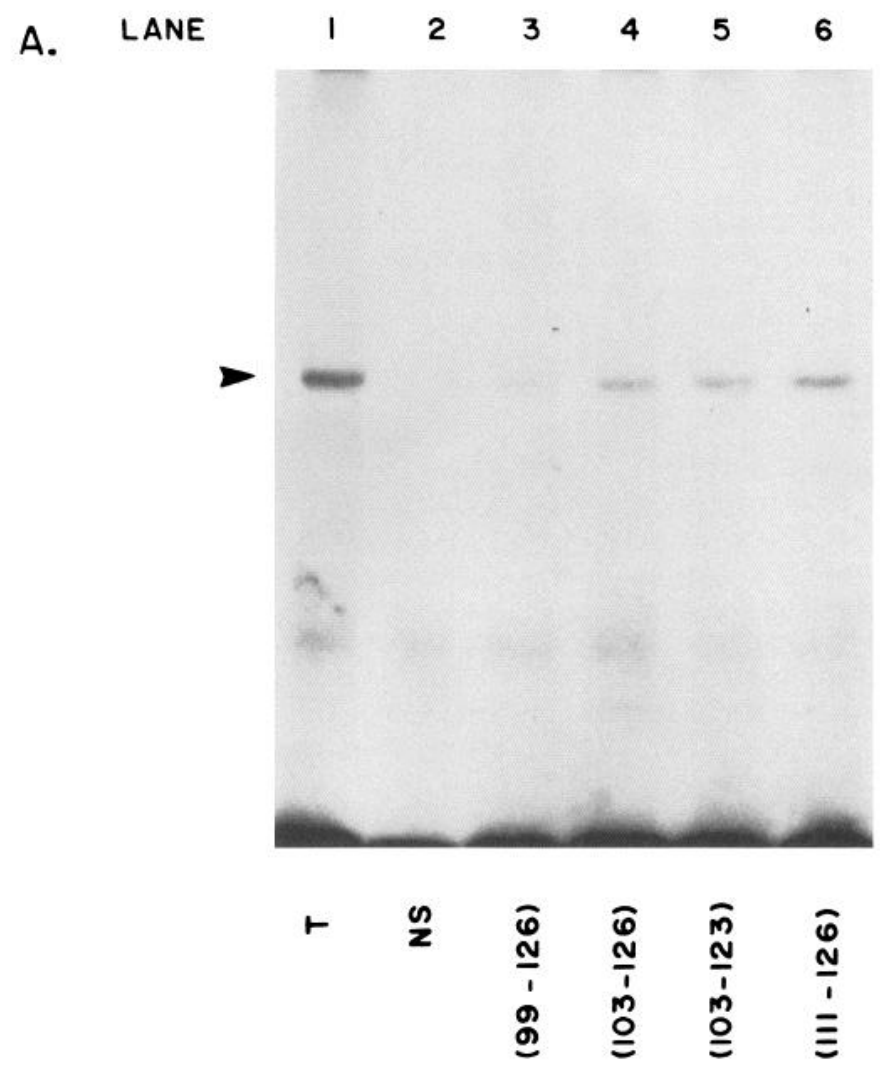

B.

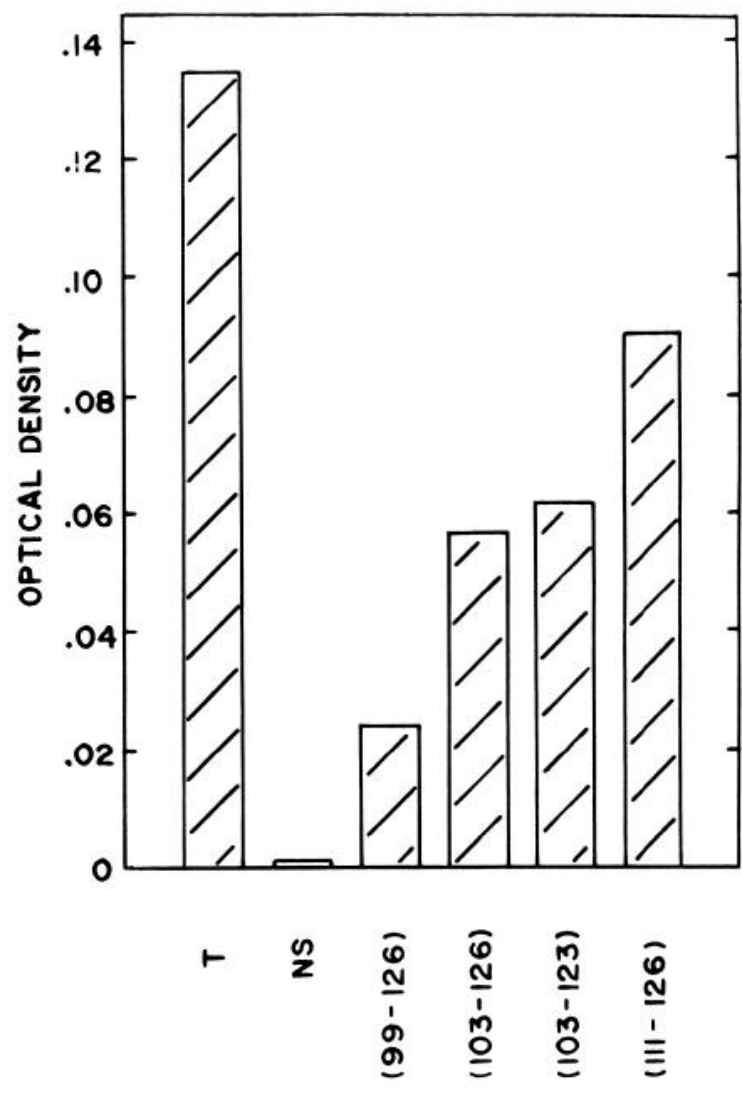

Figure 8. Ability of different ANP-related peptides to inhibit the labeling of the 116-kDa band. A, Autoradiogram of rat olfactory bulb membranes: Membranes were incubated with 100 pM ${ }^{125}$ I-ANP in the absence (lane 1) or presence (lanes 2-6) of various unlabeled ANP-related peptides. Membranes were cross-linked with $1 \mathrm{mM}$ DFDNB and equal amounts of protein subjected to SDS-PAGE. All peptides in lanes 3-6 were present at a final concentration of $1 \mathrm{nM}$. Lane 2 indicates the labeling of the $116 \mathrm{kDa}$ band in the presence of $1 \mu \mathrm{M}$ ANP(99-126). The $116 \mathrm{kDa}$ band is indicated by the arrow on the left. $B$, Densitometric analysis: The intensity of the labeling of the $116 \mathrm{kDa}$ band in $A$ was quantitated as described in Materials and Methods. 
$\mathrm{NH}_{2}$-terminal region. Similar results were obtained recently in a study using membranes prepared from guinea pig cerebellum and thalamus/hypothalamus (Quirion et al., 1986). These ANPrelated peptides are similar, however, in that they all possess a disulfide bridge between cysteine residues at positions 105 and 121. The inability of ANP(111-126) to inhibit the binding of ${ }^{125}$ I-ANP to rat olfactory bulb membranes demonstrated the structural significance of the disulfide bridge to the binding potency of ANP-related peptides.

In peripheral bioassay model systems in which ANP produces clear physiological effects, it appears that alterations in the COOH-terminal region and disulfide bridge of ANP-related peptides are deleterious to biological potency. The rank order of potency of ANP-related peptides to produce renal vasodilation and natriuresis/diuresis in the canine kidney was ANP(99126) $>$ ANP(103-126) $=$ ANP(103-125) $\gg$ ANP(103-123) (Wakitani et al., 1985). Similar results were obtained in the rat kidney (Tang et al., 1984). Structure-activity relationships have also been studied using the ability of ANP to inhibit norepinephrine-induced contraction of rabbit aorta. Truncation of ANP(101-126) at the COOH-terminus yielded peptides that were much less potent than those truncated at the $\mathrm{NH}_{2}$-terminal region (Garcia et al., 1985). In another study, ANP(103-126) was shown to be a more potent inhibitor of precontracted rabbit aorta and chick rectum than ANP(103-123) (Geller et al., 1984). ANP(103-126) is also more potent than ANP(103-123) in its ability to decrease angiotensin II-stimulated aldosterone release by isolated adrenal cells (Campbell et al., 1985). In addition, the absence of the disulfide bridge in ANP-related peptides results in either a dramatic decrease (Schiller et al., 1985) or abolition (Misono et al., 1984) of biological activity in several of the bioassays described above. The ANP binding site present in the rat olfactory bulb displays ligand-binding properties similar to peripheral ANP receptors. This suggests that ANP binding sites in the CNS may, in fact, represent ANP receptors. Confirmation of this hypothesis awaits further studies on the physiological effects of ANP in the CNS.

\section{Functional significance of ANP binding sites in the brain}

Previous reports from this and other laboratories have demonstrated the existence of binding sites for ANP in many regions of the CNS of the rat, guinea pig, and monkey using autoradiography (Gibson et al., 1986; Quirion et al., 1984, 1986). In these studies, the highest levels of ANP binding sites were localized to the olfactory bulb and the circumventricular organs. Unlike the circumventricular organs, however, the olfactory bulb is located behind the blood-brain barrier and must therefore interact with ANP that is derived from within the CNS. The recent demonstration of ANP in the rat olfactory bulb using immunohistochemistry and radioimmunoassay (Kawata et al., 1986) suggests that ANP may be functioning as a neurotransmitter or neuromodulator in this brain structure. Since ANP in the brain may be functioning in a completely different capacity than in the periphery, 2 different receptor systems may be required.

Structural differences between peptide receptors located in the $\mathrm{CNS}$ and in the periphery have been shown in recent studies of cholecystokinin (CCK) receptors. Pancreatic CCK receptors of mice exhibit an apparent molecular mass of $80 \mathrm{kDa}$ and 120 $\mathrm{kDa}$ under reducing and nonreducing conditions, respectively (Sakamoto et al., 1983, 1984). Cerebral cortical CCK receptors, however, migrate with an apparent molecular mass of $55 \mathrm{kDa}$ in the absence or presence of reducing agent (Sakamoto et al., 1984). These differences in the structural characteristics of CCK receptors are thought to underlie the differences seen in the binding affinity of various CCK analogs for brain versus pancreatic CCK receptors (Sakamoto et al., 1984).

Insulin receptors in the brain, however, exhibit ligand selec-

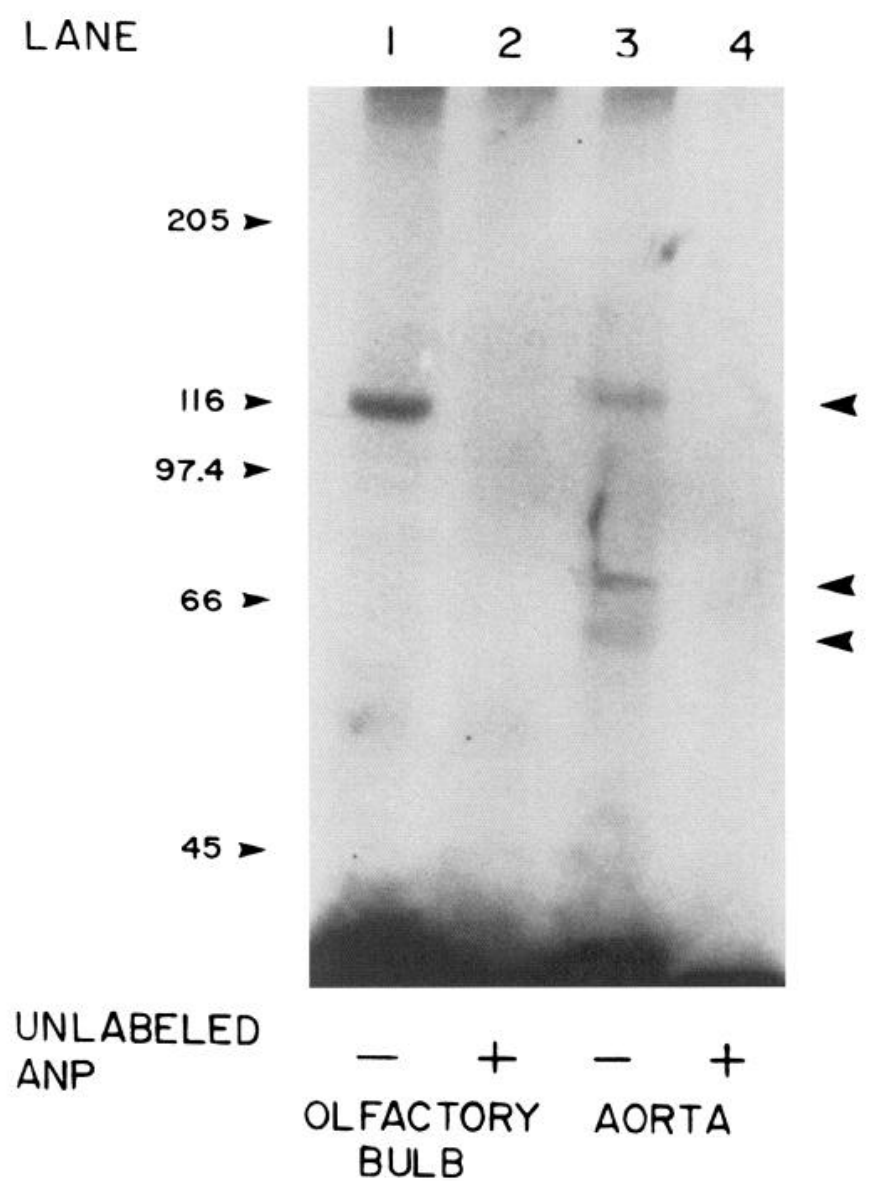

Figure 9. Autoradiogram of ${ }^{125} \mathrm{I}$-ANP cross-linked to binding sites in rat olfactory bulb and aorta membranes. Membranes from olfactory bulb (175 $\mu \mathrm{g}$ protein, lanes 1 and 2$)$ or aorta (255 $\mu \mathrm{g}$ protein, lanes 3 and 4) were incubated with 100 pM ${ }^{125}$ I-ANP in the absence $(-)$ or presence (+) of $1 \mu \mathrm{M}$ unlabeled ANP(99-126) and cross-linked using 1 mM DFDNB as described in Materials and Methods. The specifically labeled bands in rat aorta membranes are indicated by the arrows at right. The migration of proteins of known molecular mass (in $\mathrm{kDa}$ ) is shown to the left.

tivity for various insulin-related peptides comparable to peripheral insulin receptors (Havrankova et al., 1979). Insulin receptors in the CNS are also similar to insulin receptors in adipose tissue in that they are composed of 2 subunits. The molecular mass of brain insulin receptors, however, is lower than that of adipose tissue under reducing and nonreducing conditions (Ciaraldi et al., 1985; Heidenreich et al., 1983). These structural differences are believed to be attributable in part to differences in the carbohydrate composition of adipose versus brain insulin receptors (Boyd and Raizada, 1983; Heidenreich et al., 1983).

ANP binding sites in the olfactory bulb display selectivity towards various ANP-related peptides, which is similar to that observed with peripheral ANP receptors. It is difficult, however, to make precise comparisons between the proteins labeled with ${ }^{125} \mathrm{I}-\mathrm{ANP}$ in brain versus peripheral tissues since there is little agreement concerning the biochemical characteristics of peripheral ANP binding sites. A single protein band was labeled by ${ }^{125} \mathrm{I}$-ANP in rat olfactory bulb membranes displaying a molecular mass of $116 \mathrm{kDa}$. This is similar to results obtained using bovine and rat adrenal cortical (Misono et al., 1985) and rat renal cortical (Yip et al., 1985) membranes, in which a single 125 or $140 \mathrm{kDa}$ band was observed, respectively. While multiple bands were labeled by ${ }^{125} \mathrm{I}$-ANP in membranes prepared from 
bovine adrenal cortex (Meloche et al., 1986) and rabbit aorta (Vandlen et al., 1985), one of the bands identified in these 2 tissues displayed a high molecular mass (114 and $120 \mathrm{kDa}$, respectively), which is comparable to the molecular mass reported for ANP binding sites in the rat olfactory bulb in the present report. It is possible, therefore, that ANP binding sites in the olfactory bulb are structurally similar to peripheral ANP receptors. In this case, small differences in the biochemical characteristics of ANP receptors in the brain versus peripheral organs could be due to tissue-specific glycosylation, similar to the findings described above for the insulin receptor. The glycoprotein nature of kidney ANP receptors has been suggested by the increased electrophoretic mobility of the putative renal ANP receptor after digestion with glycosidases (Yip et al., 1985).

The differences observed in the biochemical characteristics of peripheral ANP receptors could be attributable to proteolysis and/or incomplete reduction of membranes by reducing agents. This was shown to be the explanation for the diverse results obtained describing the subunit composition of insulin receptors in liver and fat tissue (Massague et al., 1980). Future studies comparing the biochemical characteristics of ANP receptors in both peripheral tissues and in the brain are needed to establish the structural identity of the ANP receptor and to determine whether different molecular subtypes of the ANP receptor exist.

\section{References}

Bennet, H. P. J., C. A. Browne, and S. Solomon (1981) Purification of the two major forms of rat pituitary corticotropin using only reversed-phase liquid chromatography. Biochemistry 20:4530-4538.

Bloch, K. D., J. A. Scott, J. B. Zisfein, J. T. Fallon, M. N. Margolies, C. E. Seidman, G. R. Matsueda, C. J. Homcy, R. M. Graham, and J. G. Seidman (1985) Biosynthesis and secretion of proatrial natriuretic factor by cultured rat cardiocytes. Science 230:1168-1171.

Boyd, F. T., and M. K. Raizada (1983) Effects of insulin and tunicamycin on neuronal insulin receptors in culture. Am. J. Physiol. 245: C283-C287

Campbell, W. B., M. G. Currie, and P. Needleman (1985) Inhibition of aldosterone biosynthesis by atriopeptins in rat adrenal cells. Circ. Res. 57: 113-118.

Cantin, M., and J. Genest (1985) The heart and the atrial natriuretic factor. Endocrine Rev. 6: 107-127.

Carrier, F., G. Thibault, E. L. Schiffrin, R. Garcia, J. Gutkowska, M. Cantin, and J. Genest (1985) Partial characterization and solubilization of receptors for atrial natriuretic factor in rat glomeruli. Biochem. Biophys. Res. Commun. 132: 666-673.

Charticr, L., E. L. Schiffrin, and G. Thibault (1984) Effect of atrial natriuretic factor (ANF)-related peptides on aldosterone secretion by adrenal glomerulosa cells: Critical role of the intramolecular disulphide bond. Biochem. Biophys. Res. Commun. 122: 171-174.

Ciaraldi, T., R. Robbins, J. W. Leidy, P. Thamm, and P. Berhanu (1985) Insulin receptors on cultured hypothalamic cells: Functional and structural differences from receptors on peripheral target cells. Endocrinology 116: 2179-2185.

Currie, M. G., D. M. Geller, J. Chao, H. S. Margolius, and P. Needleman (1984) Kallikrein activation of a high molecular weight atrial peptide. Biochem. Biophys. Res. Commun. 120: 461-466.

De Bold, A. J. (1985) Atrial natriuretic factor: A hormone produced by the heart. Science 230:767-776.

De Bold, A. J., H. B. Borenstein, A. T. Veress, and H. Sonnenberg (1981) A rapid and potent natriurctic response to intravenous injection of atrial myocardial extract in rats. Life Sci. 28: 89-94.

De Lean, A., J. Gutkowska, N. McNicoll, P. W. Schiller, M. Cantin, and J. Genest (1984) Characterization of specific receptors for atrial natriuretic factor in bovine adrenal zona glomerulosa. Life Sci. 35: 2311-2318.

Garcia, R., G. Thibault, N. G. Seidah, C. Lazure, M. Cantin, J. Genest, and $M$. Chretien (1985) Structure-activity relationships of atrial natriuretic factor (ANF). II. Effect of chain-length modifications on vascular reactivity. Biochem. Biophys. Res. Commun. 126: 178-184.

Geller, D. M., M. G. Currie, K. Wakitani, B. R. Cole, S. P. Adams, K. F. Fok, N. R. Siegel, S. R. Eubanks, G. R. Galluppi, and P. Needleman (1984) Atriopeptins: A family of potent biologically active peptides derived from mammalian atria. Biochem. Biophys. Res. Commun. 120: 333-338.

Gibson, T. R., G. M. Wildey, S. Manaker, and C. C. Glembotski (1986) $\Lambda$ utoradiographic localization and charactcrization of atrial natriuretic peptide binding sites in the rat central nervous system and adrenal gland. J. Neurosci. 6: 2004-2011.

Glembotski, C. C., and T. R. Gibson (1985) Molecular forms of immunoactive atrial natriuretic peptide released from cultured rat atrial myocytes. Biochem. Biophys. Res. Commun. 132: 1008-1017.

Glembotski, C. C., G. M. Wildey, and T. R. Gibson (1985) Molecular forms of immunoactive atrial natriuretic peptide in the rat hypothalamus and atrium. Biochem. Biophys. Res. Commun. 129: 671678.

Goodfriend, T. L., M. E. Elliot, and S. A. Atlas (1984) Actions of synthetic atrial natriuretic factor on bovine adrenal glomerulosa. Life Sci. 35: 1675-1682.

Havrankova, J., M. Roth, and M. J. Brownstein (1979) Concentrations of insulin and of insulin receptors in the brain arc independent of peripheral insulin levels. Studies of obese and streptozotocin-treated rodents. J. Clin. Invest. 64: 636-642.

Heidenreich, K. A., N. R. Zahniser, P. Berhanu, D. Brandenburg, and J. M. Olefsky (1983) Structural differences between insulin receptors in the brain and peripheral target tissues. J. Biol. Chem. 258: 85278530 .

Hirata, Y., M. Tomita, H. Yoshimi, and M. Ikeda (1984) Specific receptors for atrial natriuretic factor (ANF) in cultured vascular smooth muscle cells of rat aorta. Biochem. Biophys. Res. Commun. 125: 562568.

Hirose, S., F. Akiyama, M. Shinjo, H. Ohno, and K. Murakami (1985) Solubilization and molecular weight estimation of atrial natriuretic factor receptor from bovine adrenal cortex. Biochem. Biophys. Res. Commun. 130: 574-579.

Jacobowitz, D. M., G. Skofitsch, H. R. Keiser, R. L. Eskay, and N. Zamir (1985) Evidence for the existence of atrial natriuretic factorcontaining neurons in the rat brain. Neuroendocrinology 40: 92-94.

Kawata, M., K. Nakao, N. Morii, Y. Kiso, H. Yamashita, H. Imura, and Y. Sano (1986) Atrial natriuretic polypeptide: Topographical distribution in the rat brain by radioimmunoassay and immunohistochemistry. Neuroscience 16: 521-546.

Laemmli, U. K. (1970) Cleavage of structural proteins during the assembly of the head of bacteriophage T4. Nature 227: 680-685.

Lowry, O. H., N. J. Rosenbrough, A. L. Farr, and R. J. Randall (1951) Protein measurement with the Folin phenol reagent. J. Biol. Chem. 193: 265-275.

Lynch, D. R., K. M. Braas, and S. H. Snyder (1986) Atrial natriuretic factor receptors in rat kidney, adrenal gland, and brain: Autoradiographic localization and fluid balance dependent changes. Proc. Natl. Acad. Sci. USA (in press).

Manning, P. T., D. Schwartz, N. C. Katsube, S. H. Holmberg, and P. Needleman (1985) Vasopressin-stimulated release of atriopeptin: Endocrine antagonists in fluid homeostasis. Science 229: 395-397.

Massague, J., P. F. Pilch, and M. P. Czech (1980) Electrophoretic resolution of three major insulin receptor structures with unique subunit stoichiometries. Proc. Natl. Acad. Sci. USA 77: 7137-7141.

Matsuoka, H., M. Ishii, T. Sugimoto, Y. Hirata, T. Sugimoto, K. Kanagawa, and $H$. Matsuo (1985) Inhibition of aldosterone production by $\alpha$-human atrial natriuretic polypeptide is associated with an increase in cGMP production. Biochem. Biophys. Res. Commun. 127: 1052-1056.

Meloche, S., H. Ong, M. Cantin, and A. De Lean (1986) Affinity crosslinking of atrial natriuretic factor to its receptors in bovine adrenal zona glomerulosa. J. Biol. Chem. 261: 1525-1528.

Misono, K. S., H. Fukumi, R. T. Grammer, and T. Inagami (1984) Rat atrial natriuretic factor: Complete amino acid sequence and disulfide linkage essential for biological activity. Biochem. Biophys. Res. Commun. 119: 524-529.

Misono, K. S., R. T. Grammer, J. W. Rigby, and T. Inagami (1985) Photoaffinity labeling of atrial natriuretic factor receptor in bovine and rat adrenal cortical membranes. Biochem. Biophys. Res. Commun. 130: 994-1001.

Nakamura, M., G. Katsuura, K. Nakao, and H. Imura (1985) Antidipsogenic action of $\alpha$-human atrial natriuretic polypeptide administered intracerebroventricularly in rats. Neurosci. Lett. 58: 1-6.

Napier, M. A., R. L. Vandlen, G. Albers-Schonberg, R. F. Nutt, S. Brady, T. Lyle, R. Winquist, E. P. Faison, L. A. Heinel, and E. H. 
Blaine (1984) Specific membrane receptors for atrial natriuretic factor in renal and vascular tissues. Proc. Natl. Acad. Sci. USA 81: 59465950.

Needleman, P., S. P. Adams, B. R. Cole, M. G. Currie, D. M. Geller, M. L. Michener, C. B. Saper, D. Schwartz, and D. G. Standaert (1985) Atriopeptins as cardiac hormones. Hypertension 7: 469-482.

Quirion, R., M. Dalpe, and T.-V. Dam (1986) Characterization and distribution of receptors for the atrial natriuretic peptides in mammalian brain. Proc. Natl. Acad. Sci. USA 83: 174-178.

Quirion, R., M. Dalpe, A. De Lean, J. Gutkowska, M. Cantin, and J. Genest (1984) Atrial natriuretic factor (ANF) binding sites in brain and related structures. Peptides 5: 1167-1172.

Sakamoto, C., I. D. Goldfine, and J. A. Williams (1983) Characterization of cholecystokinin receptor subunits on pancreatic plasma membranes. J. Biol. Chem. 258: 12707-12711.

Sakamoto, C., J. A. Williams, and I. D. Goldfine (1984) Brain CCK receptors are structurally distinct from pancreas CCK receptors. Biochem. Biophys. Res. Commun. 124: 497-502.

Saper, C. B., D. G. Standaert, M. G. Currie, D. Schwartz, D. M. Geller, and $P$. Needleman (1985) Atriopeptin-immunoreactive neurons in the brain: Presence in cardiovascular regulatory areas. Science 227: 1047-1049.

Schenk, D. B., L. K. Johnson, K. Schwartz, H. Sista, R. M. Scarborough, and J. A. Lewicki (1985a) Distinct atrial natriuretic factor receptor sites on cultured bovine aortic smooth muscle and endothelial cells. Biochem. Biophys. Res. Commun. 127: 433-442.

Schenk, D. B., M. N. Phelps, J. G. Porter, R. M. Scarborough, G. A. McEnroe, and J. A. Lewicki (1985b) Identification of the receptor for atrial natriuretic factor on cultured vascular cells. J. Biol. Chem. 260: 14887-14890.

Schiffrin, E. L., L. Chartier, G. Thibault, J. St.-Louis, M. Cantin, and J. Genest (1985) Vascular and adrenal receptors for atrial natriuretic factor in the rat. Circ. Res. 56: 801-807.

Schiller, P. W., L. Maziak, T. M.-D. Nguyen, J. Godin, R. Garcia, A. De Lean, and M. Cantin (1985) Synthesis and biological activity of a linear fragment of the atrial natriuretic factor (ANF). Biochem. Biophys. Res. Commun. 131: 1056-1062.
Schwartz, D., D. M. Geller, P. T. Manning, N. R. Siegel, K. F. Fok, C. E. Smith, and P. Needleman (1985) Ser-Leu-Arg-Arg-Atriopeptin. III: The major circulating form of atrial peptide. Science 229: 397400.

Sills, M. A., K. Q. Nguyen, and D. M. Jacobowitz (1986) Increases in heart rate and blood pressure produced by microinjections of atrial natriurctic factor into the AV3V region of the rat brain. Peptides (in press).

Skofitsch, G., D. M. Jacobowitz, R. L. Eskay, and N. Zamir (1986) Distribution of atrial natriuretic factor-like immunoreactive neurons in the rat brain. Neuroscience 16: $917-948$.

Tanaka, I., K. S. Misono, and T. Inagami (1984) Atrial natriuretic factor in rat hypothalamus, atria and plasma: Determination by specific radioimmunoassay. Biochem. Biophys. Res. Commun. 124: 663668.

Tang, J., R. J. Webber, J. K. Chang, J. Kiang, and E. T. Wei (1984) Depressor and natriuretic activities of several atrial peptides. Regulat. Peptides 9: 53-59.

Vandlen, R. L., K. E. Arcuri, and M. A. Napier (1985) Identification of a receptor for atrial natriuretic factor in rabbit aorta membranes by affinity cross-linking. J. Biol. Chcm. 260: 10889-10892.

Von Schroeder, H. P., E. Nishimura, C. H. S. McIntosh, A. M. J. Buchan, N. Wilson, and J. R. Ledsome (1985) Autoradiographic localization of binding sites for atrial natriuretic factor. Can. J. Physiol. Pharmacol. 63: 1373-1377.

Wakitani, K., B. R. Cole, D. M. Geller, M. G. Currie, S. P. Adams, K. F. Fok, and P. Needleman (1985) Atriopeptins: Correlation between renal vasodilation and natriuresis. Am. J. Physiol. 249: F49-F53.

Winquist, R. J. (1985) The relaxant effects of atrial natriuretic factor on vascular smooth muscle. Life Sci. 37: 1081-1087.

Yip, C. C., L. P. Laing, and T. G. Flynn (1985) Photoaffinity labeling of atrial natriuretic factor receptors of rat kidney cortex plasma membranes. J. Biol. Chem. 260: 8229-8232.

Zamir, N., G. Skofitsch, R. L. Eskay, and D. M. Jacobowitz (1986) Distribution of immunoreactive atrial natriurctic peptides in the central nervous system of the rat. Brain Res. 365: 105-111. 